Review article

\title{
COMPLEX GEODETIC RESEARCH IN UKRAINIAN ANTARCTIC STATION "ACADEMICIAN VERNADSKY" (YEARS 2002 - 2005, 2013-2014)
}

\author{
Kornyliy Tretyak, Volodymyr Hlotov, Yuriy Holubinka, Khrystyna Marusazh \\ Institute of Geodesy \\ National University Lviv Polytechnic, \\ Lviv, Ukraine
}

\begin{abstract}
In this paper is given an information about complex geodetic research in Ukrainian Antarctic station "Academician Vernadsky". Research were carried by Lviv polytechnic scientists, during Antarctic expeditions in years 2002 - 2005, 2013, 2014. Main objectives of the studies were: (a) study of the islands glaciers surface volumes changes in Antarctic archipelago and Antarctic Peninsula using terestrial laser scaning and digital terrestrial stereophotogrammetry survey; (b) investigation of Penola strain tectonic fault, using the results of precise GNSS observations.
\end{abstract}

Keywords: Argentinian islands, glacier, terrestrial laser scanning, digital stereo photogrammetric survey, Penola strain tectonic fault, GNSS observations, geodynamic polygon.

\section{Introduction}

In April 2014 another Ukrainian expedition was organized, which was attended by authors of this paper. We had a several objectives, and main ones were: performing of new cycle of terrestrial stereo photogrammetric survey and laser scanning of Argentinian archipelago islands glaciers; GNSS observation on local geodynamic polygon of Argentinian archipelago. These tasks became traditional for Ukrainian Antarctic expeditions, since researches, performed during 2002 - 2005, and 2013 (Hlotov, 2003, Hlotov, 2005, Hlotov, 2006).

\section{Investigation of islands glaciers changes}

First glaciological research in Antarctic peninsula were started by Poland meteorologist Henry Artstovsky in 1900. These studies were dedicated to islands of 
Flanders Bay. In 1908 glaciological surveys of Peterman and Bot islands glaciers were done (Gourdon, 1908).

During 1935 - 1936 British scientists of Antarctic expedition did meteorological surveying of Argentinian islands and glaciological research of Western coast of Graham Land (Fleming, 1996). The results of these studies showed that coastal glaciers were originated from the ice shell, which had decreased for this moment to a several small ice shelves. Photos of western part of Galindez island shown in the fig. 1.

Starting from the 1960, on the territory of one of the biggest islands of Argentinian archipelago - Galindez, English scientists started detail glaciological observations (Thomas, 1963). Based on the results of these measurements, glaciers mass balance was determined, also temperature of snow cover, glaciers movements were measured, sources of accumulation and factors causing ablation of ice masses were also determined.

In paper (Thomas, 1963) author is notifying that main sources of ice masses accumulation are: snowfall, and influence of sublimation. Main factors of ablations are: wind and drift erosion, melting of snow cover and ice in the rocks.

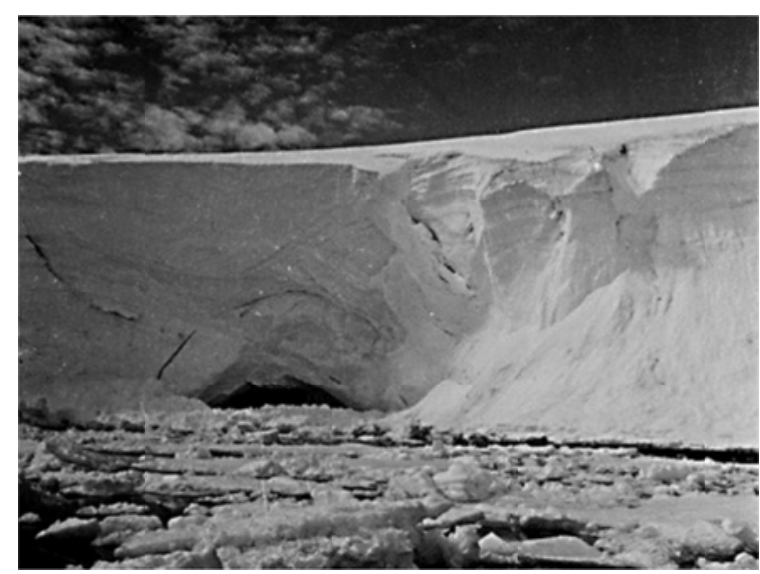

a)

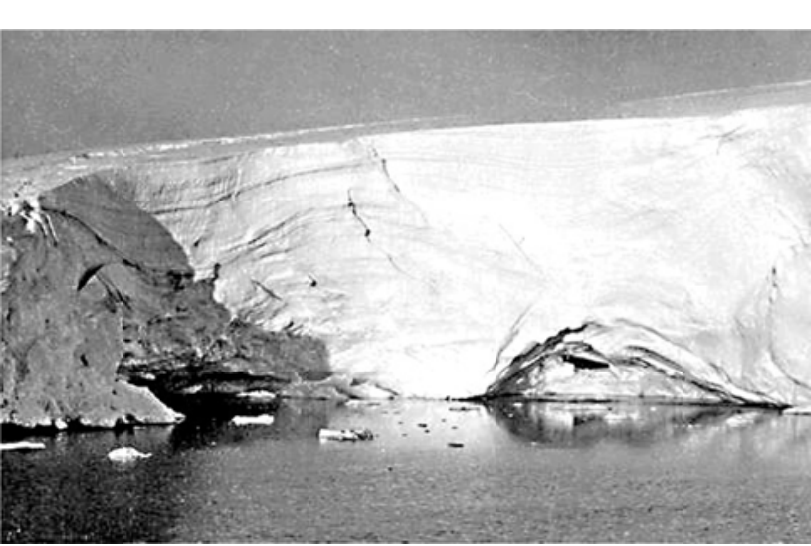

b)

Fig. 1. Photo of western part of Galindez glacier a - 1935, b - February of 1936 (Fleming, 1996)

Glaciological studies of Argentinian islands were continued during British Antarctic expeditions in 1964 - 1966. In particular, on the islands Galindez and Skua (fig. 2, 3) which were covered by ice up to $40 \%$ and $50 \%$, measurements of periodic snow cover thickness were done, as well as ablation values and glacier movement were determined (Sadler, 1968).

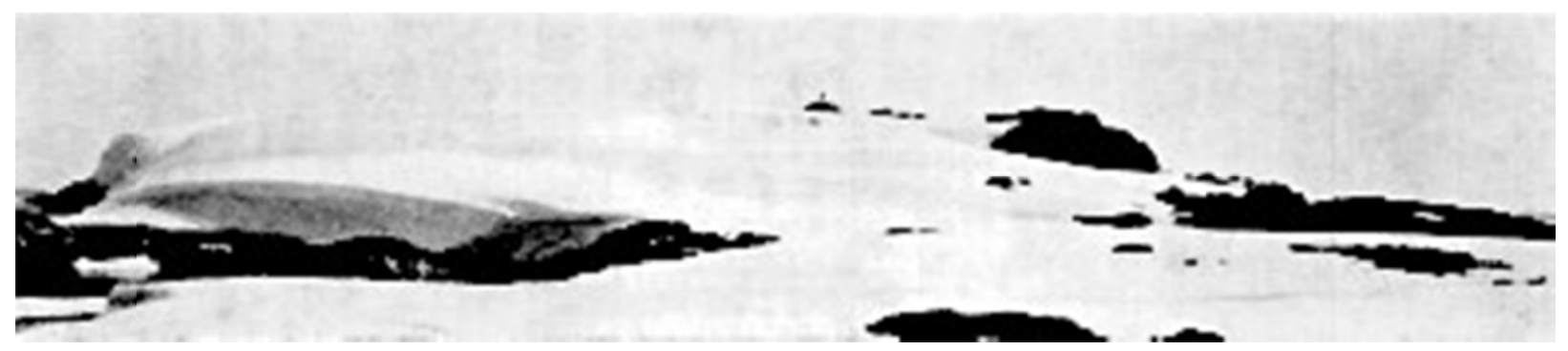

Fig. 2. Panoramic view of Galindez island, 1966 (Sadler, 1968) 


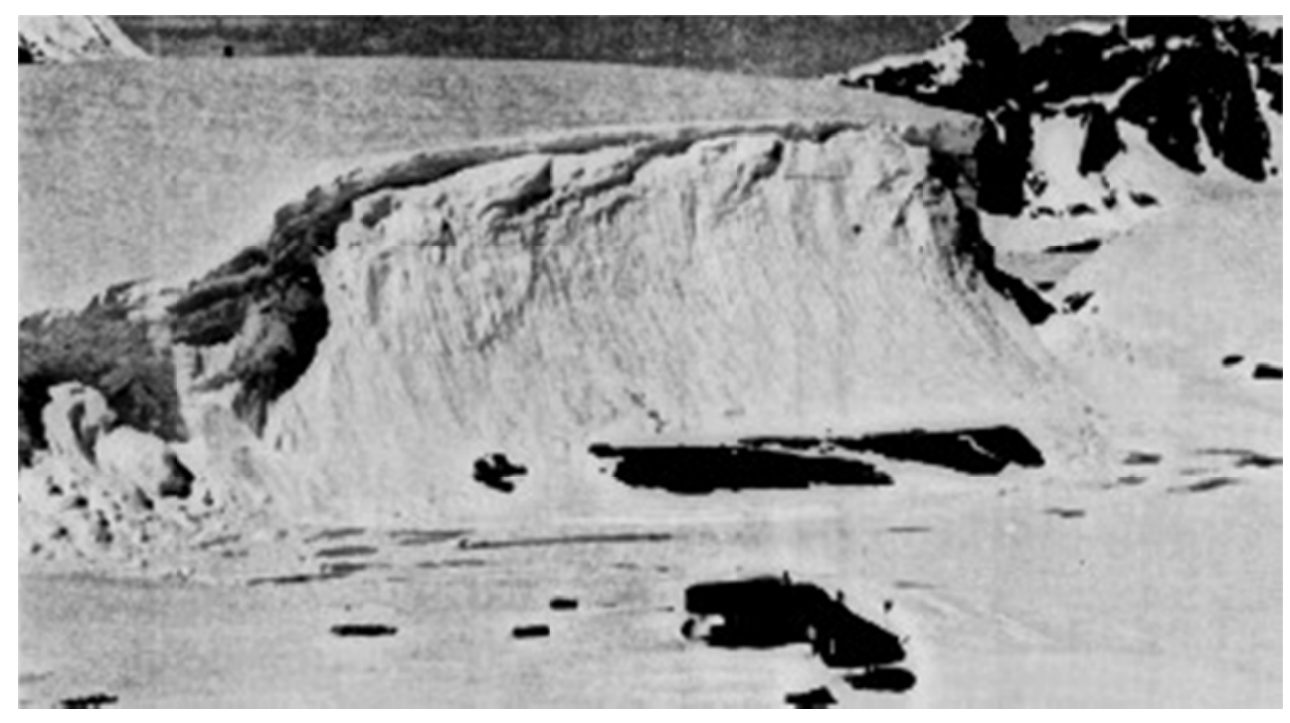

Fig. 3. Panoramic view of Winter island, 1966

Investigation on the Galindez island showed that for three parts of the glacier almost the same quantity of snow has accumulated, this fact indicates that snow accumulation doesn't change with altitude above the sea level.

Observation results showed that most part of ice dome is moving with minor velocity. At the same time, further investigation in maximal movements zones allowed to estimate yearly-average displacements of the glacier: $9 \mathrm{~cm}$ of water column equivalent. This movement value is only one of the reasons of total glacier damaging, because other part of ablation consisted mainly drains and drift of noncompacted snow.

As one of possible reasons of glacier movement was considered a reduction of main ice, as a result of plastic deformation. It causes slipping of lower glacier surface with changeful velocity on the fractured bedrock surface, this processes causes deformation and cracks of the glacier. Cracks are at right angles to the direction of glacier movement, and split it to rectangular blocks (Thomas, 1963).

However, the question arises: what causes the necessity to monitor the glaciers movements, deformations, and determination of their geometrical parameters? Glaciologist find out, that islands glaciers are very "sensual" to external temperature changes and actually are acting as "litmus test" with help of whiich is possible to prognoses climate changes, not only for local areas, but also for the all planet. For the last 50 years, 244 glaciers, of the west coastline of Antarctic peninsula decreased in dimensions (Cook, 2005). Also, the results of Galindez glacier monitoring during 1956 - 2004 showed decreasing of its size (fig. 4).

As we can see, this task is very important. But, its realization, using contact methods is very complicated, because, in most cases inaccessible glaciers need to be observed (Hlotov, 2003). 


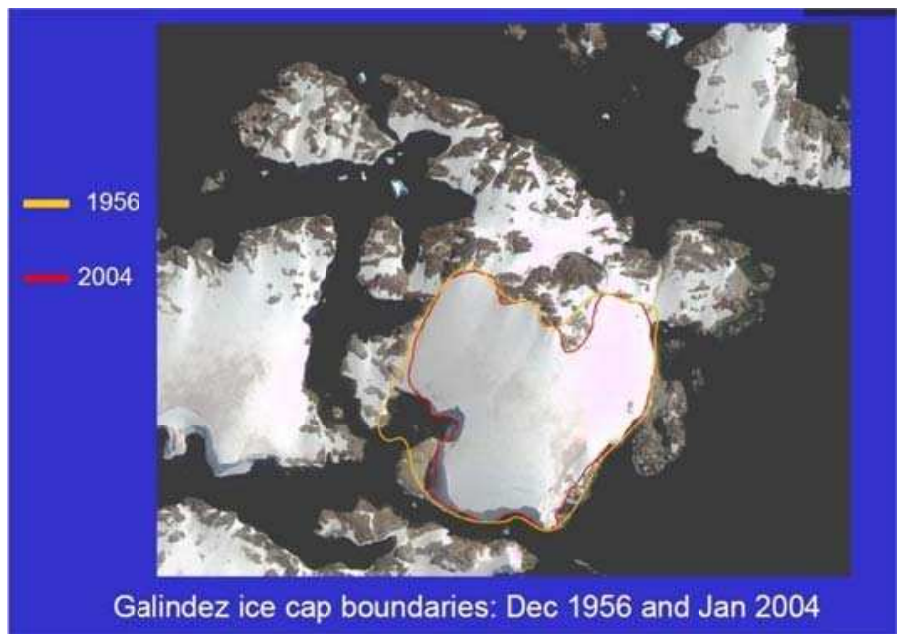

Fig. 4. Boarders of Galindez glacier in 1956 and 2004

\subsection{Method of determining the volume of surface glaciers}

During 19 seasonal Antarctic expedition digital stereo photogrammetric surveying of western and southern parts of Galindez had been done. Same work was done for the southern part of Winter glacier. Digital camera EOS 450D with 12 million pixels CCD was used for this purpose. During the survey, range of focal length was changed respectively: $18,35,55 \mathrm{~mm}$. Causes of surveying: normal and rejected.

In previous expedition, for the first time, terrestrial laser scanning had been used together with stereo photogrammetric survey. Field measurements were done by Faro Focus 3D laser scanner (Tretyak, 2013).

Application of such complex method allowed us to get full digital terrain model (DTM), since not always we had opportunity for scanning of different parts of the glacier surface (caves, grottoes, depressions etc.). Implementation of two methods allowed us to fill glacier "white spots". Besides scanning results allowed to get control points for the orientation of stereo pairs.

Before starting the field measurements approximate positions for laser scanner and reference points had been selected, using existing maps and satellite images. Since maximal possible measured distance of Faro Focus 3D is $120 \mathrm{~m}$, selection was done in order to not exceed distance of $100 \mathrm{~m}$ to the scanned glacier, and distance between reference points of $60 \mathrm{~m}$. Field measurements were done from 06.04.2014 to 07.04.2014. Scanning resolution was set to achieve $1.5 \mathrm{~cm}$ at a distance from scanner to glacier $-100 \mathrm{~m}$, respectively duration of scanning on one station was $30-45$ minutes.

Each point cloud (scan), received from particular scanning position was determined in local coordinate system, this system is coinciding with internal axis of the scanner. That is way, each point cloud (scan), received from the particular scanning position had its own coordinate system. The problem of transformation of each scan to one coordinate system was solved by using at least three reference points, that were visible on the neighbouring scans, in our case, this value was increased to $5-6$ reference points.

Since, these observations need to be conducted in next cycles, and change of the glaciers volumes need to be to be determined, it was necessary to connect merged point clouds into a common coordinate system. This issue was solved, by using 
GNSS observation of each reference point. GNNS observations were done in kinematic mode, as reference station we used permanent station VER1, it is located near Vernadsky station. Data processing was done in Leica Geo Office software, as a result WGS84 coordinates in UTM projection were computed. RMS error of coordinates computation did not exceed $5 \mathrm{~cm}$.

Laser scanning data processing was performed in Leica Cyclone software. On the first stage data filtering for elimination of erroneous points (outliers) due to complicated weather conditions, angle of reflection of scanned glacier was done automatically, using software.

After data filtering, scans merging (registration) and transformation to WGS84, UTM coordinate system was done basic on the determined coordinates of the reference points.

As result, point cloud models of two islands glaciers (Galindez and Winter) were received (fig. 5 - 7).

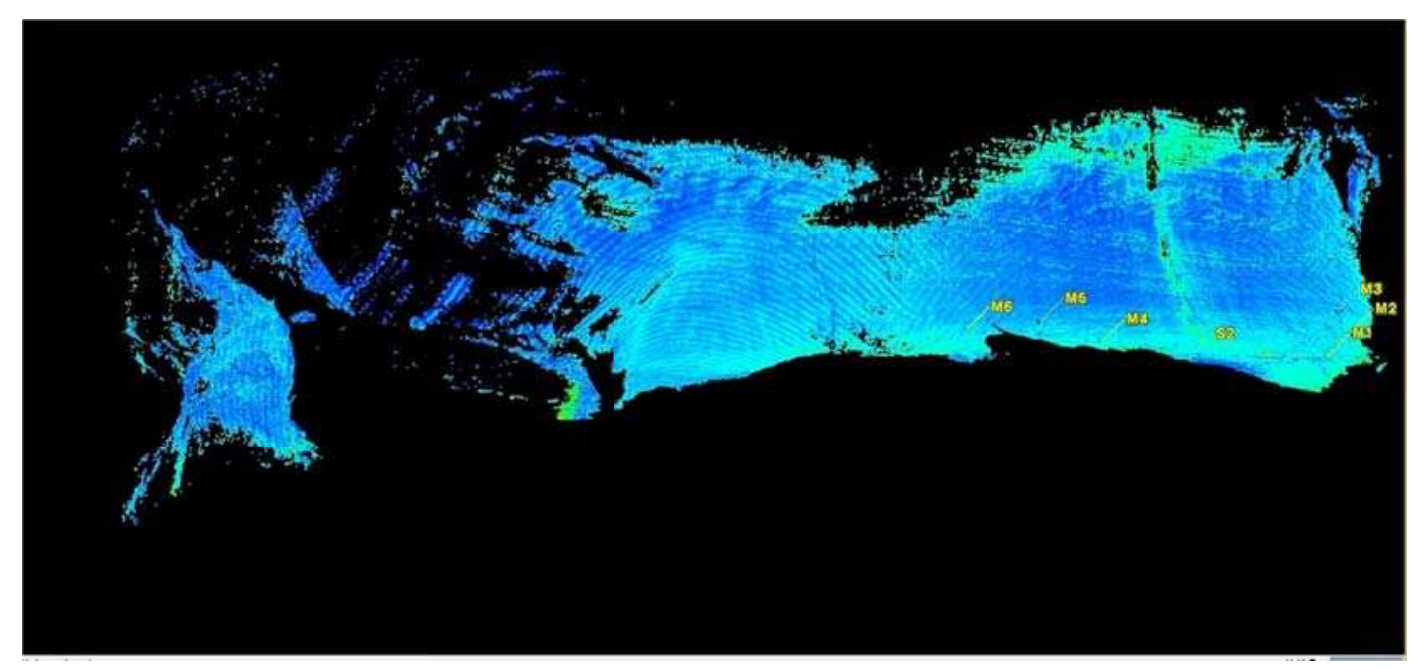

Fig. 5. Point cloud model of western part of Galindez island

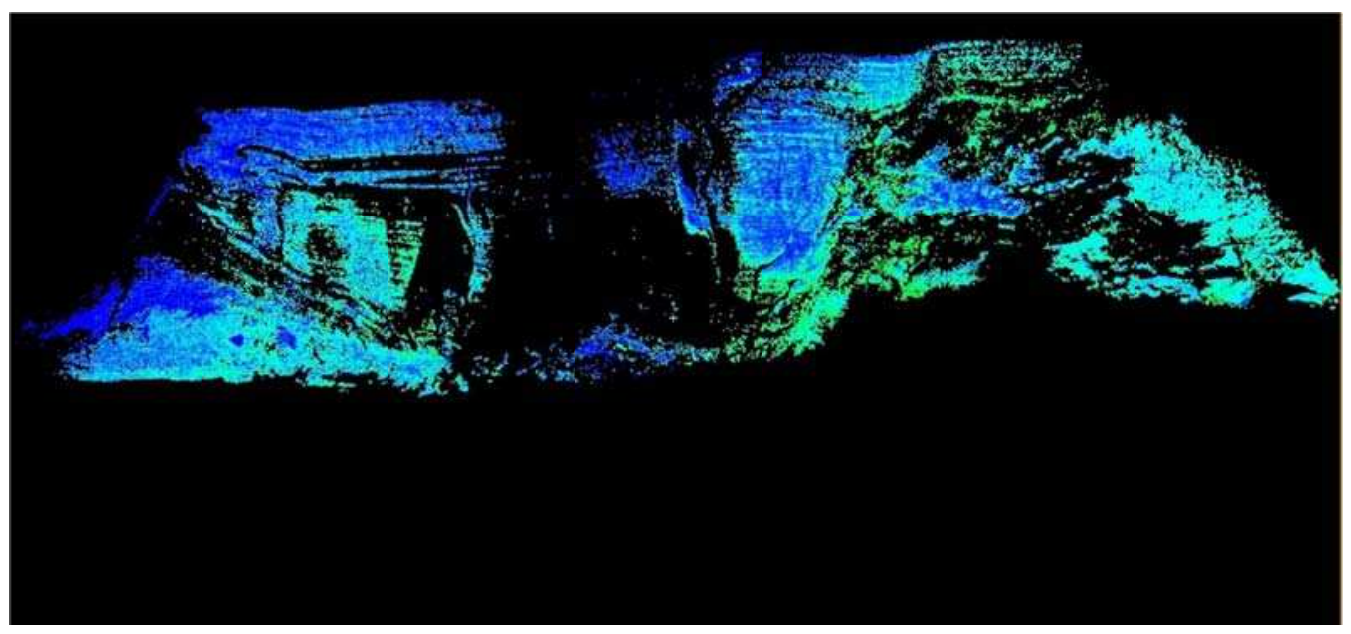

Fig. 6. Point cloud model of southern part of Galindez isiland 


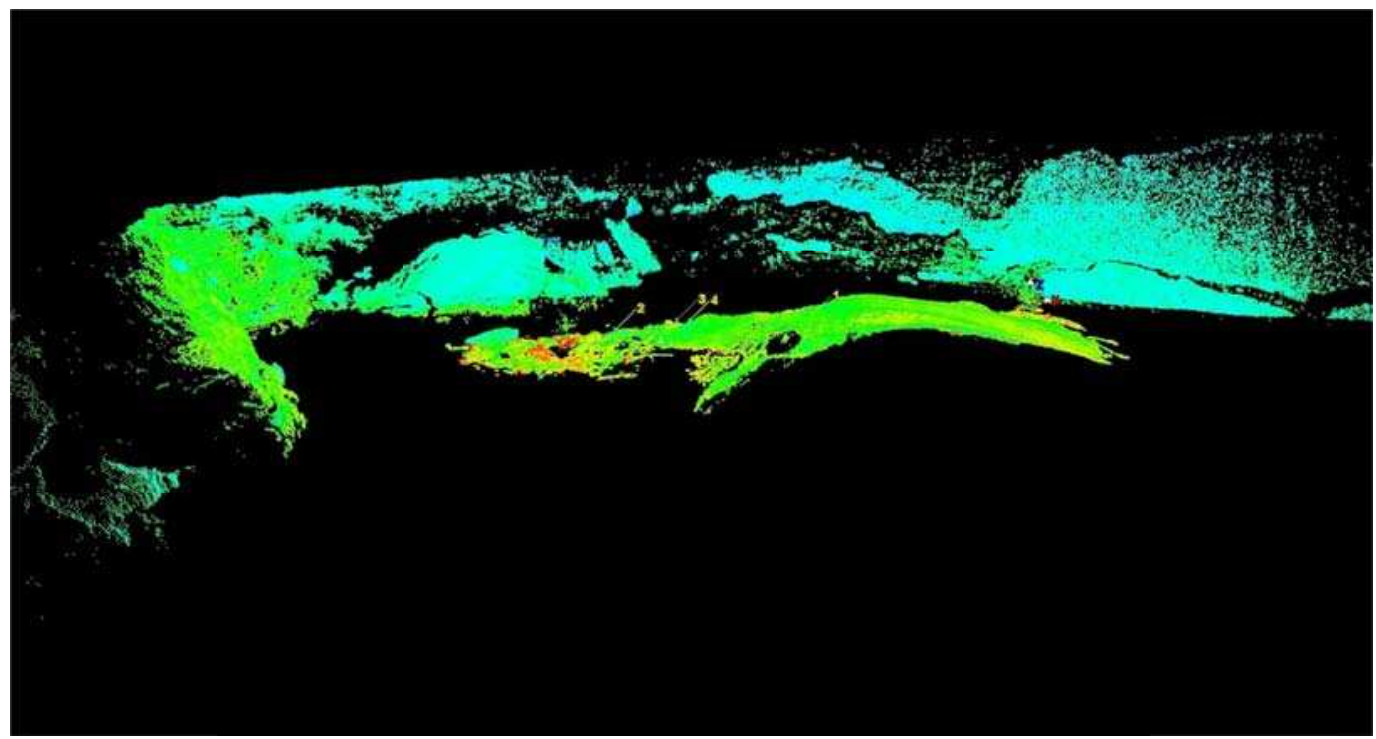

Fig. 7. Point cloud model of southern part of Winter island

For determination of surface volumes we used digital terrain models, determined in 2013, using digital stereo photogrammetric method and laser scanning in 2014 (Tretyak, 2013). Figures $8-13$ are showing panoramic images of studied glaciers in 2013 and 2014.

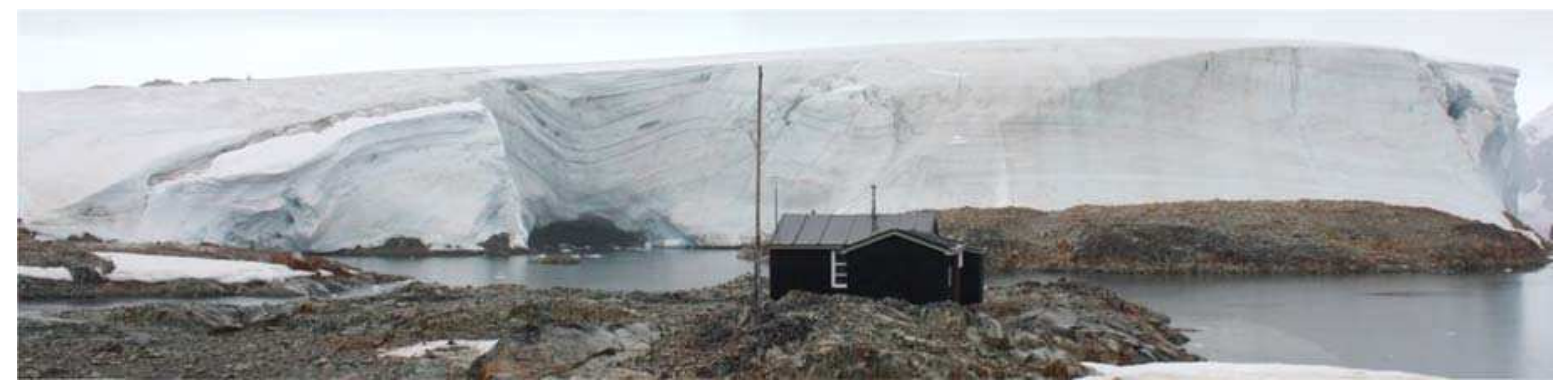

Fig. 8. Panoramic image of western part of Galindez island glacier (2013)

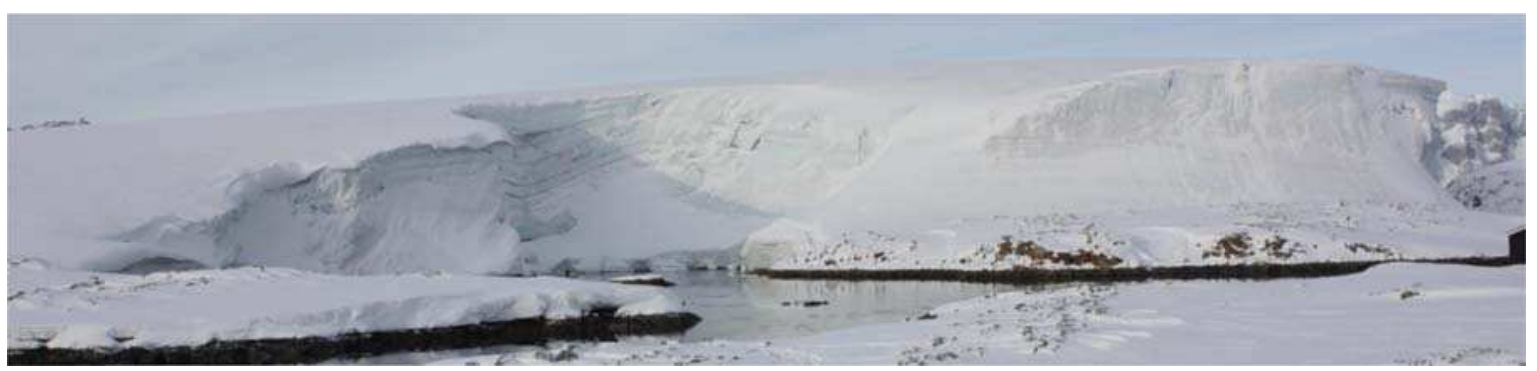

Fig. 9. Panoramic image of western part of Galindez island glacier (2014) 


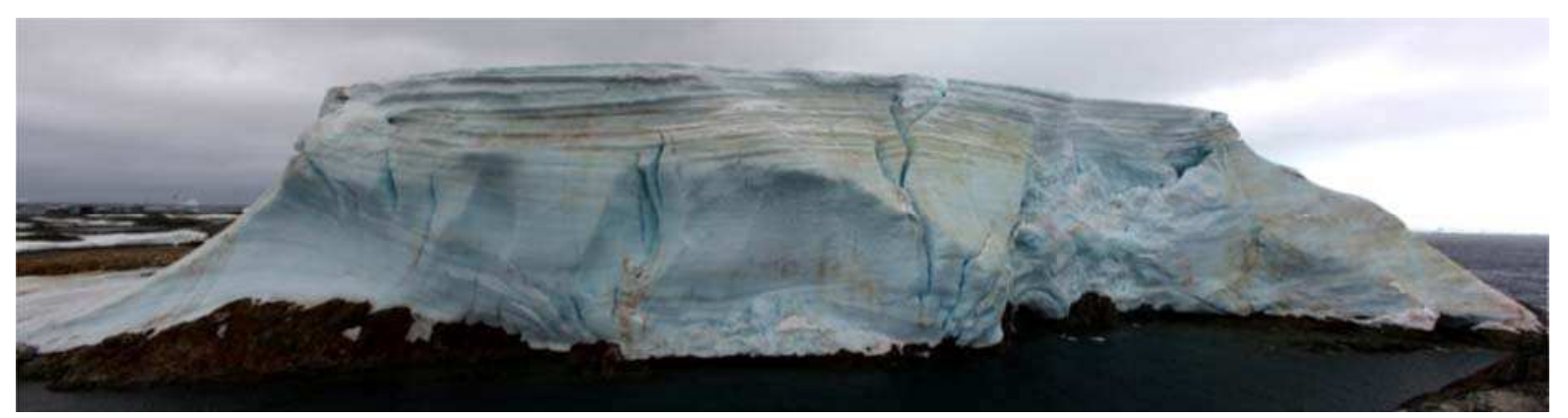

Fig. 10. Panoramic image of southern part of Galindez island glacier (2013)

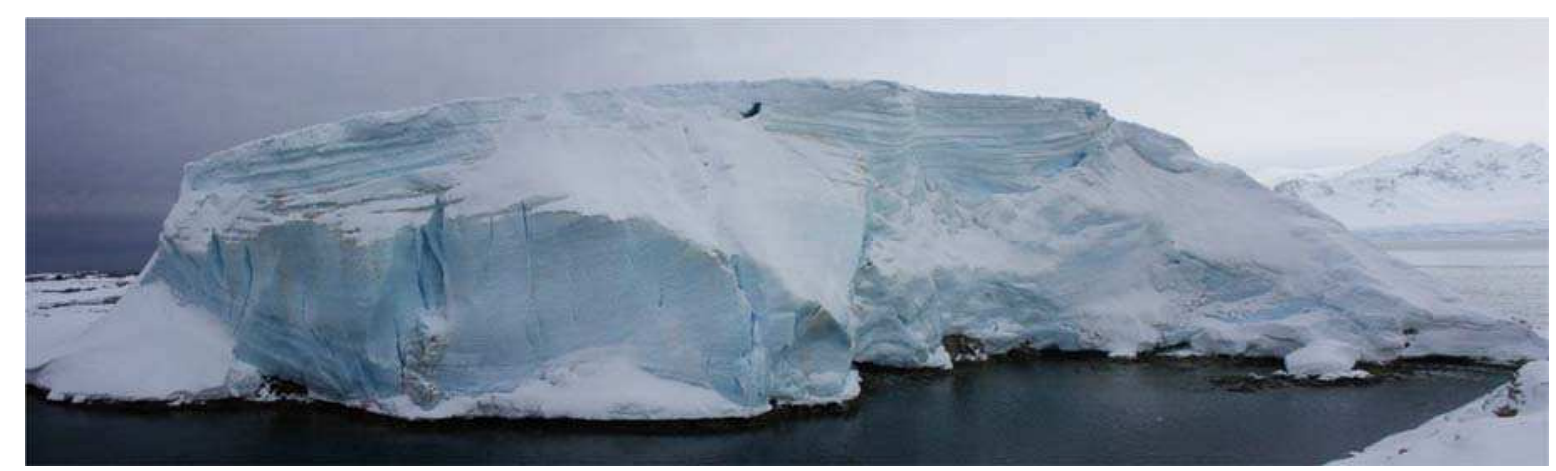

Fig. 11. Panoramic image of southern part of Galindez island glacier (2014)

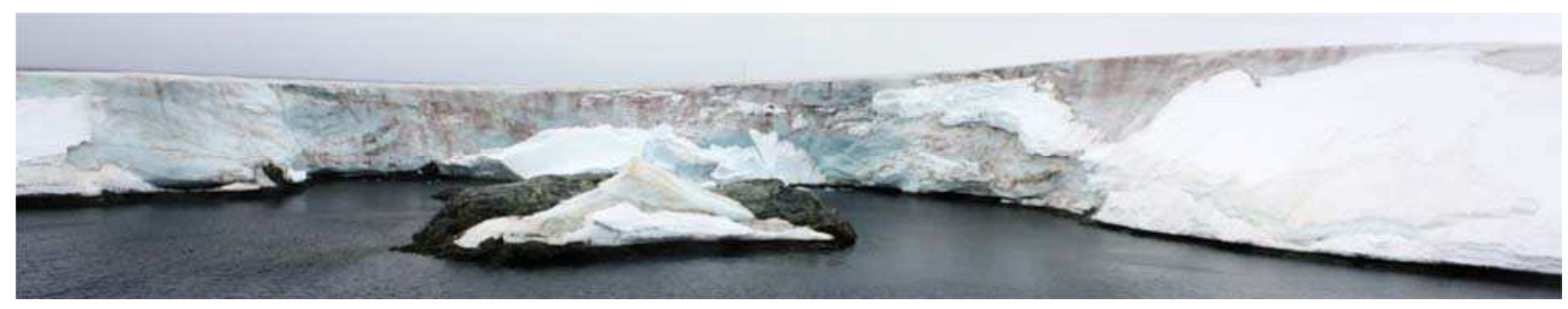

Fig. 12. Panoramic image of southern part of Winter island glacier (2013)

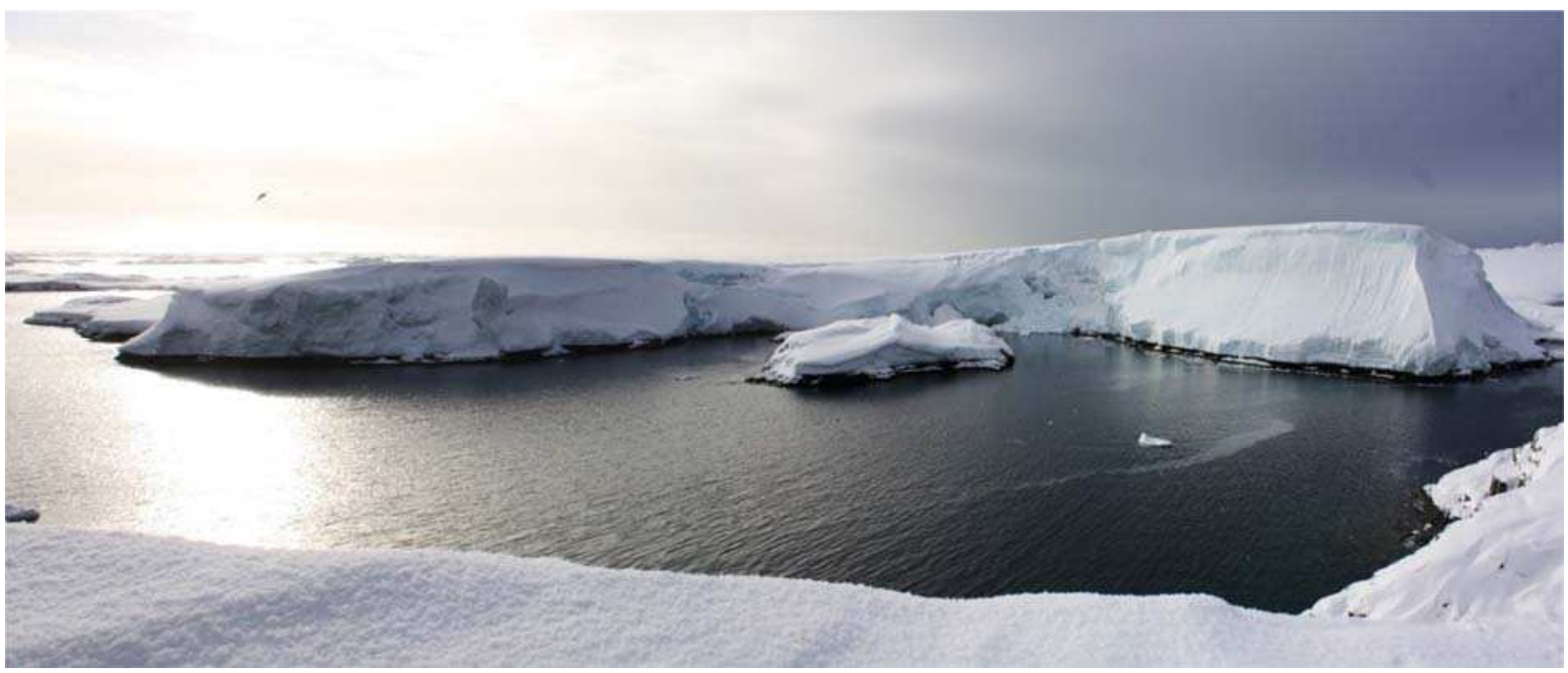

Fig. 13. Panoramic image of southern part of Winter island glacier (2014) 
Since, one of the problems of stereo photogrammetric method realization is a technology of DTM creation of the glaciers surface. We proposed the algorithm for optimization of grid spacing for DTM construction for glaciers volumes determination.

An important step of the technology is the choice of the method and parameters for DTM construction. In this case, the DTM was defined as regular placing of points in grid nodes with square elementary cell.

First of all DTM grid spacing is influenced by such values: errors of points coordinates determination, errors of line lengths, and errors of determination of depth, area, and volume of the object. Since there are some requirements of precision for volumes determinations, let us assume that during grid parameters determination, relative error of volume is known, as value of function error, and relative errors of glacier geometrical parameters as unknown arguments. This can be interpreted as inverse task of errors theory, when we need to determine relative limiting errors of arguments in this way, that relative function errors would not exceed of given value.

Algorithm of optimal grid spacing determination consists of the following:

1) Calculation of a priory accuracy estimation of points coordinates.

2) Setting accuracy of glacier volume determination. It is known that this error is $1 \%$.

3) Determination of relative limiting errors of object depth.

4) Calculation of relative limiting errors of area determination.

5) Calculation of optimal grid spacing.

Calculated grid spacing allows to determine the number and density of grid nodes, which will be used for measurements.

For DTM creation of glacier surfaces we determined grid spacing, using shoved above algorithm. Dimensions of studied objects are shown in table 1.

Table 1. Glaciers dimensions

\begin{tabular}{|l|c|c|c|}
\hline \multirow{2}{*}{ Object } & \multicolumn{3}{|c|}{ Maximum dimensions } \\
\cline { 2 - 4 } & $\Delta X, \mathrm{~m}$ & $\Delta \mathrm{Z}, \mathrm{m}$ & $\Delta \mathrm{Y}, \mathrm{m}$ \\
\hline Western part of Galindez glacier & 160 & 35 & 50 \\
\hline Southern part of Galindez glacier & 175 & 40 & 30 \\
\hline Southern part of Winter glacier & 155 & 20 & 61 \\
\hline
\end{tabular}

Results of a priory accuracy estimation are shown in table 2.

Table 2. Estimation of a priory accuracy for photogrammetric coordinates

\begin{tabular}{|l|c|c|c|c|c|}
\hline \multirow{2}{*}{ Object } & \multirow{2}{*}{$B, \mathrm{~m}$} & \multirow{2}{*}{$Y_{\Phi}, \mathrm{m}$} & \multicolumn{3}{|c|}{ Values of RMS errors } \\
\cline { 4 - 7 } & & & $m_{X}, \mathrm{~m}$ & $m_{Y}, \mathrm{~m}$ & $m_{Z}, \mathrm{~m}$ \\
\hline Western part of Galindez glacier & 46 & 220 & 0,19 & 0,30 & 0,13 \\
\hline Southern part of Galindez glacier & 10 & 75 & 0,10 & 0,17 & 0,07 \\
\hline Southern part of Winter glacier & 13,5 & 150 & 0,29 & 0,47 & 0,19 \\
\hline
\end{tabular}

Relative limiting errors of depth and area determination were respectively $0,03 \%$ та 0,97\%. 
Table 3. Calculation of grid spacing and grid nodes density

\begin{tabular}{|l|c|c|c|}
\hline \multicolumn{1}{|c|}{ Object } & Area, $\mathrm{m}^{2}$ & Grid spacing, $\mathrm{m}$ & Grid nodes density \\
\hline Western part of Galindez glacier & 5600 & 1,3 & 0,6 \\
\hline Southern part of Galindez glacier & 7000 & 1,2 & 0,7 \\
\hline Southern part of Winter glacier & 3100 & 1,7 & 0,4 \\
\hline
\end{tabular}

Using calculated regular grid spacing (table 4) we developed DTM for glaciers volumes determination.

Determination of glaciers surface volumes by stereo photogrammetric and laser scanning data was done using formula:

$$
V=\sum_{i=1}^{n} h_{i} \cdot S_{i},
$$

where $h_{i}$ - heights of DTM, $S_{i}$ - area of elemental squares of DTM.

By the results of field data processing, we calculated surface volumes of three exits of two island glaciers: western and southern parts Galindez glacier, and southern part of Winter glacier. Using the results of stereo photogrammetric survey in 2013 and complex (laser scanning and stereo photogrammetric survey) in 2014 we determined changes of surface volumes of glaciers $-16000 \mathrm{~m}^{3}$ for western part of Galindez island; $500 \mathrm{~m}^{3}$ for southern part of Galindez island; $1400 \mathrm{~m}^{3}$ for southern part of Winter island (table 4).

From the table 4 we can see that average velocity of volume decreasing of the western part of Galindez glacier is $12000 \mathrm{~m}^{3} / \mathrm{year}$, which is $0.70 \mathrm{~m}$ of water column equivalent per year. Average velocity of volume decreasing of the southern part of Galindez glacier is $9150 \mathrm{~m}^{3} /$ year $-0.78 \mathrm{~m}$ of water column equivalent per year. Winter glacier is decreasing with average velocity of $8800 \mathrm{~m}^{3} / \mathrm{year}-0.70 \mathrm{~m}$ of water column equivalent per year. As we can see average velocities of glaciers decreasing are almost the same. Comparing with 60th years of the twentieth century we could argue, that speed of studied glaciers increased 8 times.

Table 4. Results of determination of surface volumes of Argentinian archipelago island glaciers

\begin{tabular}{|c|c|c|c|c|c|}
\hline \multicolumn{2}{|c|}{$\begin{array}{c}\text { Glacier of Galindez island } \\
\text { Western part }\end{array}$} & $\begin{array}{c}\text { Glacier of Galindez island } \\
\text { Southern part }\end{array}$ & \multicolumn{2}{c|}{$\begin{array}{c}\text { Glacier of Winter island } \\
\text { Southern part }\end{array}$} \\
\hline Time period & $\begin{array}{c}\text { Volume } \\
\left(\mathrm{m}^{3}\right)\end{array}$ & Time period & $\begin{array}{c}\text { Volume } \\
\left(\mathrm{m}^{3}\right)\end{array}$ & Time period & $\begin{array}{c}\text { Volume } \\
\left(\mathrm{m}^{3}\right)\end{array}$ \\
\hline $2002-2003$ & 23000 & $2002-2003$ & 1500 & $2002-2003$ & - \\
\hline $2003-2004$ & 28000 & $2003-2004$ & 350 & $2003-2004$ & 1250 \\
\hline $2004-2005$ & 17000 & $2004-2005$ & 4800 & $2004-2005$ & 4800 \\
\hline $2005-2013$ & 64000 & $2005-2013$ & 94000 & $2005-2013$ & 82000 \\
\hline $2013-2014$ & 16000 & $2013-2014$ & 500 & $2013-2014$ & 1400 \\
\hline
\end{tabular}

Figure 14 shows velocities of volume changes of studied glaciers from 2002 to 2014 in water column equivalent. 


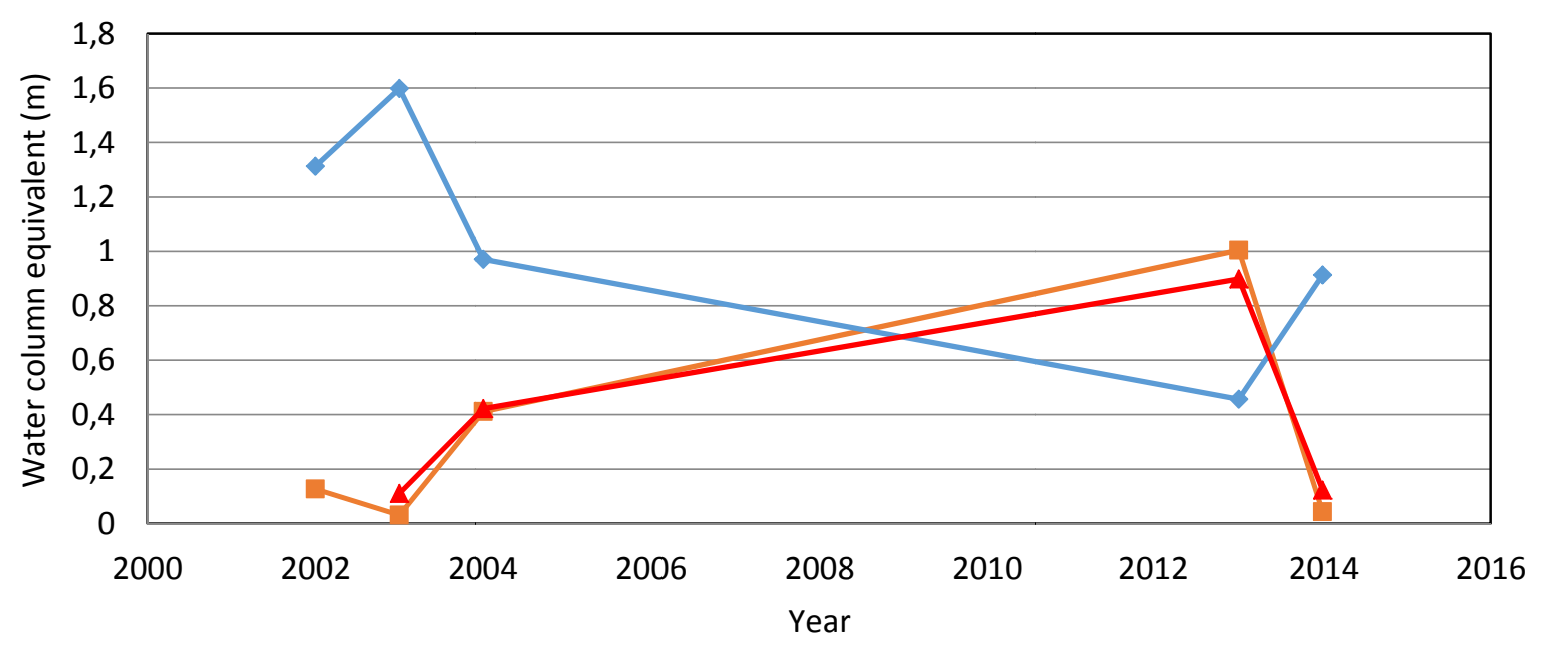

$\rightarrow-$ - Galindez glacier, southern part; $\rightarrow-$ - Galindez glacier, western part;

$\rightarrow$ - Winter glacier, southern part

Fig. 14. Surface volumes changes of studied glaciers

From the table 4 and figure 14 we can see that for periods from 2005 - 2014 melting speed of southern parts of Galindez and Winter glaciers increased. For western part of Winter glacier, melting speed, for the same period on the contrary decreased.

Analysing the results, dramatic changes can be visible, for the last nine years. This is confirmed by determined quantitative parameters by two independent methods.

\subsection{Research of tectonic fault of Penola strait (Argentinian islands archipelago)}

Particular interest in geodynamical research of Antarctic Peninsula represents the area covering tectonically active zone (in past) with modern volcanic activity. Points of GNSS observations are localized near polar stations, and are covering almost all territory of Antarctic Peninsula. Main aim of this kind of observations is research of modern tectonic activity of territories nearby to polar stations and coordinate-time "tying" of different scientific equipment. During recent years, one of the tasks of Ukrainian Antarctic expeditions is research of geodynamical processes and tectonic activity of the region of Argentinian islands. In the field of special attention of geophysics is a territory of tectonic fault of Penola strait. This fault separates Argentinian archipelago from the Antarctic Peninsula (in particular Galindez island, where Vernadsky station is located). To supplement geological-geophysical data and for research of modern geodynamical processes of the region, precise geodetic network was developed, and first cycles of GNSS observations were conducted.

Scientific researches on Argentinian islands territory were started by Belgian scientist in the late of XIX century under the direction of Adrian Gerlach. Results of these studies was the first geological map of these areas. Further geological-tectonic studies were conducted by British scientists. The best geological zoning, based on the cartographical basis of research areas had been done by British Antarctic service. Detailed retrospective tectonic-geological review of archipelago Argentinian islands is published in (Geological map of the Southern Graham Land, 1981) by the, results of geological and paleomagnetic studies of British geologist. 
Results of investigation of magnetic field time variations and geological research, in paper (Bahmutov, 1998, Bahmutov, 2006, Maksymchuk et al., 2002), assume the availability of tectonic activity of the region of Argentinian island (fig. 15).

The data of geological map (Geological map of the Southern Graham Land, 1981) showed that of tectonic fault coincides with fairway of Penola strait, and this corresponds to geomorphological analysis of the territory.

Analysis of the geological and geophysical results indicates about insufficient knowledge of tectonic structure of Antarctic Peninsula. Geodetic methods, in particular local GNSS networks, could supply information about modern geodynamic of the peninsula by new data.

Due to insufficient knowledge of tectonic structure of Antarctic Peninsula and differences between geological-geomorphological studies and tectonic-magnetic observations in spatial tracking of Penola strait tectonic fault, occur a necessity of precise geodetic network creation for geodynamical purposes on the research territory. This kind of network should be used for performing of repeated cycles of GNSS observations and determination of kinematic characteristics of Argentinian islands.

Built geodynamical polygon covers southern-eastern part of islands by $15 \mathrm{~km}$ radius, and part of Antarctic Peninsula. Together with benchmark VER1 network includes 8 points. Centres of geodetic points were mounted in to the rocks. External part of the centre is metal rod, $40 \mathrm{~cm}$ long with notch for forced centring of GNSS antenna. Satellites visibility on all points provided at altitude of $10-15^{0}$. Average distance between points is $7-8 \mathrm{~km}$, maximal distance is $17 \mathrm{~km}$, minimal -2.5 . all geodetic heights of points are in between $20-30 \mathrm{~m}$. Measurements were done using double frequency GPS receivers Trimble 4800, Leica SR-399 SR-9500, single frequency receiver Trimble 4600LS.

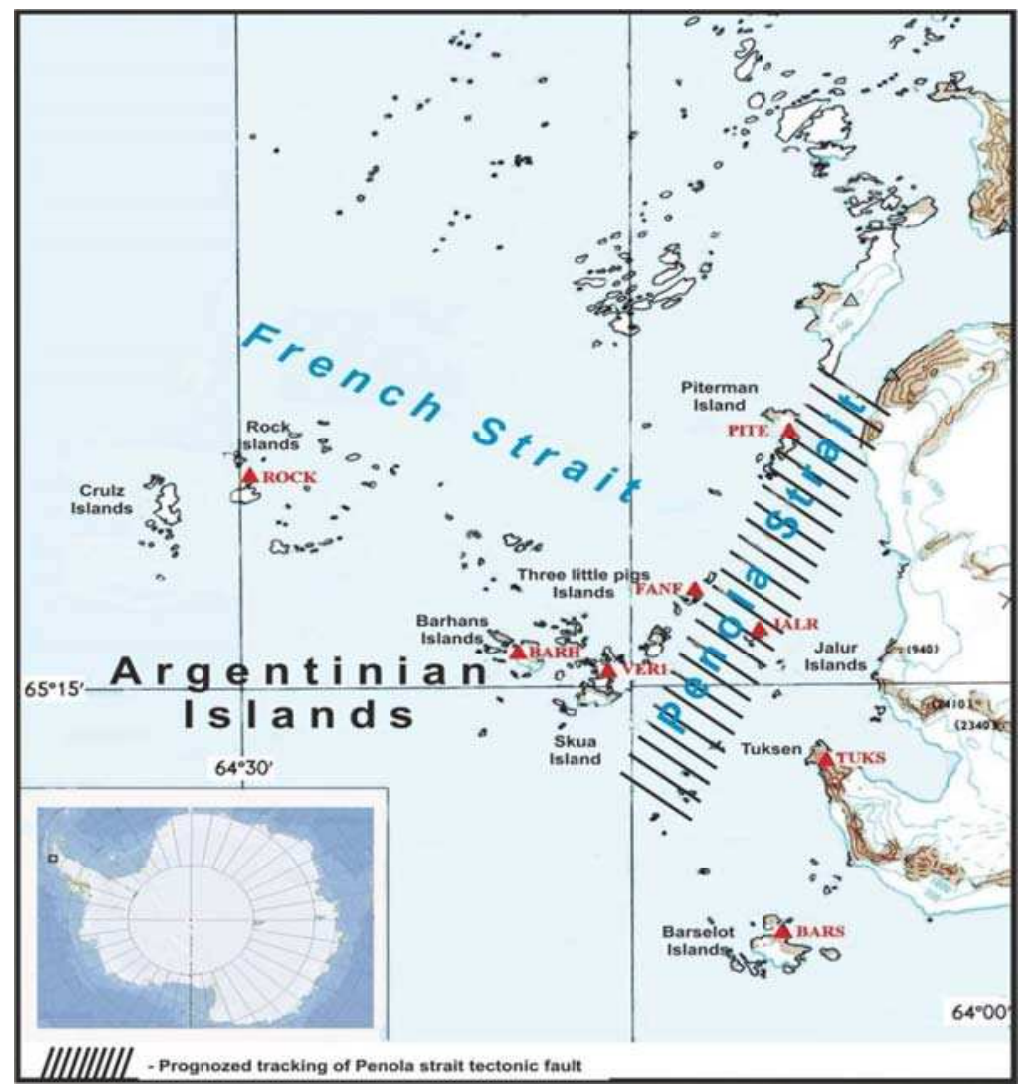

Fig. 15. Scheme of geodynamic polygon of Argentinian islands 
Second cycle of observations was done in April 2005. For measurements were used: double frequency GPS receivers Ashtech Z-12, Leica SR-399 SR-9500, Javad TPSHIPER_GGD, and single frequency receiver Thales i Ashtech ProMark2.

Third cycle was done in April 2014, only double frequency receivers: two Trimble R7, and two Leica GPS1200 were used.

Technical specifications of three cycles are shown in table 5.

Table 5. Technical characteristics of repeated cycles of GNSS observations

\begin{tabular}{|c|c|c|c|c|c|}
\hline \multicolumn{3}{|c|}{ Cycle Number } & 1 & 2 & 3 \\
\hline \multicolumn{3}{|c|}{ Total duration of observations } & $\begin{array}{c}12.02- \\
28.022003\end{array}$ & $\begin{array}{c}23.03- \\
01.042005\end{array}$ & $\begin{array}{c}5.04- \\
7.04 .2014 \\
\end{array}$ \\
\hline \multicolumn{3}{|c|}{$\begin{array}{l}\text { Measurement of one vector duration } \\
\text { (hours) }\end{array}$} & $2-12$ & $5-24$ & $14-24$ \\
\hline \multicolumn{3}{|c|}{$\begin{array}{l}\text { Number of repeated vectors } \\
\text { measurements }\end{array}$} & $1-6$ & $1-5$ & - \\
\hline \multicolumn{3}{|c|}{ Number of measured vectors } & 37 & 68 & 20 \\
\hline \multirow{2}{*}{ RMS } & Average & $\mathrm{M}_{\mathrm{XY}}, \mathrm{mm}$ & 3.0 & 1.5 & 1.7 \\
\hline & Maximal & $\mathrm{M}_{\mathrm{XY}}, \mathrm{mm}$ & 3.0 & 1.5 & 2.6 \\
\hline
\end{tabular}

As we can see from the table measurements accuracy is much higher in second and third cycles, comparing with a first cycle.

Third cycle observations were done on points: PITE, VER1, FANF JALR, TUKS (fig.15). This is related with hard weather conditions. Also developed measurements time schedule, provided 3 times observations of each point of the network, by 3 different receivers. Unfortunately, this program was not realized due to reduced duration of expedition.

Data processing was done in Leica Geo Office software. Before data adjustment, network connection to Antarctic permanent network was done. As a result, ITRF2000 coordinates of points, and horizontal displacements were determined. Displacement scheme is shown on the figure 16.

Displacements vectors of geodetic points (vector lengths corresponds to $1 \mathrm{~cm}$ displacement): 1) horizontal displacement, by the results of $3-2$ cycles; 2 ) horizontal displacement, by the results of $2-3$ cycles; 3 ) predicted tracking tectonic blocks of the area.

Determined for the period 2005 - 2014 horizontal displacements of points of geodynamic polygon are different by direction and values within the margins of tectonic blocks, displayed on the fig. 16. Vectors of points JALR and TUKS have western direction and are 8.1 and $4.0 \mathrm{~mm}$. Displacements of points PITE and FANF have southern direction with values of 17.6 and $6.8 \mathrm{~mm}$. BARH moved to southernwestern direction, and the value is $8.0 \mathrm{~mm}$. 


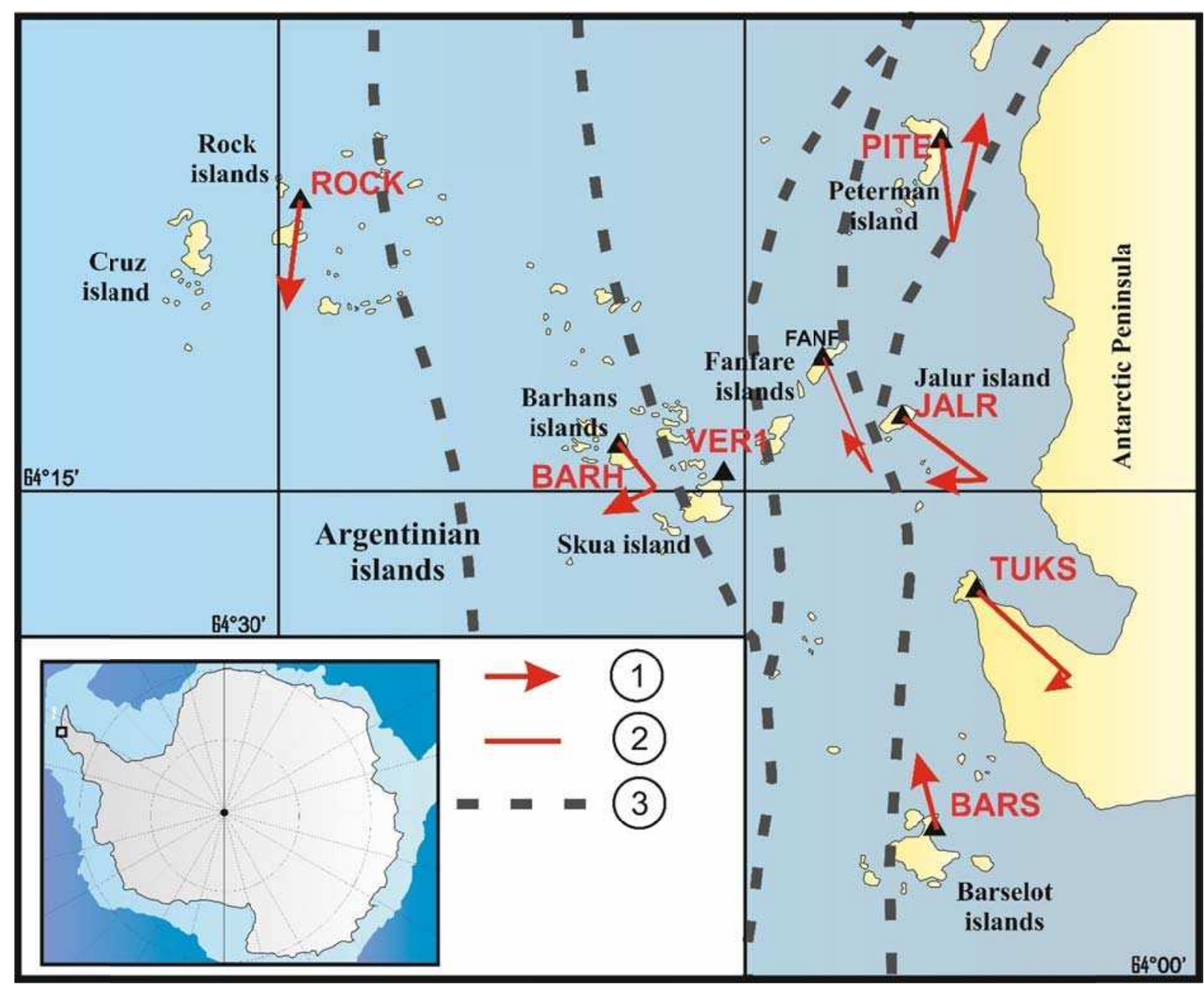

Fig. 16. Scheme of horizontal displacements of geodynamical polygon of Argentinian islands and Antarctic Peninsula

\section{Conclusions}

Results of stereo photogrammetric surveying confirmed high changes of surface volumes of island glaciers of Argentinian archipelago.

Application of terrestrial laser scanning allowed us to control and confirm precision of stereo photogrammetric surveys.

Using developed algorithm of DTM grid optimization, created digital models of glaciers and their surface volumes determined.

Results of determination of melting velocity for the glaciers of Gallindez and Winter islands are indicating increasing of their melting. For Galindez island velocity is not uniform, for western part of island it is slowing, for Galindez southern part and Winter southern part velocity increases equally.

Comparing with 60 of XX century, average velocities of glaciers melting increased almost 8 times, and are: for western part of Galindez island $0.70 \mathrm{~m}$ of water column; for Southern part of Galindez island $-0.78 \mathrm{~m}$ of water column; for southern part of Winter island $-0.70 \mathrm{~m}$ of water column.

In further investigations we are planning to continue monitoring of glaciers volumes changes. Also, we are going to use aerial photography with UAV's for these 
kind of studies, what would allow us to monitor changes of all glaciers and also increase their number.

Determined horizontal displacements of geodynamic polygon points for the period of $2005-2014$ are different by the direction and values. Maximal displacement is $17.6 \mathrm{~mm}$ for point PITE (Peterman island), minimal - for TUSK point (Antarctic Peninsula).

For further research we are planning to perform observed GNSS data, using Bernese GNSS software, with adding new GNSS permanent data from nearest stations. It would allow us to expand research area, in the margins of Antarctic Peninsula.

\section{Acknowledgment}

These researches were performed during Ukrainian Antarctic expeditions and with support of Ukrainian Antarctic centre.

\section{References}

Bahmutov, V. G. (1998). Geologicheskij obzor arhipelaga Argentinskie ostrova i prilegajushhih teritorij Antarkticheskogo poluostrova [Geological survey of the Argentine Islands archipelago and adjacent areas of the Antarctic Peninsula]. Bjuleten Ukraïnskogo Antarktichnogo Centru [Bulletin of Ukrainian Antarctic Center], 2, 77-84.

Bahmutov, V. G. (2006). Jevoljucija i geodinamika osnovnyh struktur zapadnoj Antarktiki v mezozoe-kajnozoe: sovremennye predstavlenija [The evolution and geodynamics of basic structures of the western Antarctic Mesozoic-Cenozoic: modern ideas]. Ukrainskij antarktichnij zhurnal [Ukrainian antarctic journal], 4, 5263.

Cook, A. J., Fox, A. J., Vaughan, D. G., \& Ferrigno, J. G. (2005). Retreating glacier fronts on the Antarctic Peninsula over the past half-century. Science, 308 (5721), 541-544. doi: 10.1126/science.1104235

Fleming, W.L.S. (1940). Relic glacial forms on the western seaboard of Graham Land. Geographical Journal, 96(2), 93-100.

Hlotov, V. (2003). Monitoring malyh lednikov kak indikatorov izmenenij klimata v rajone Antrakticheskogo polu ostrova [Monitoring of small glaciers as indicators of climate change in the Antarctic Peninsula]. Ukrainskij antarktichnij zhurnal [Ukrainian Antarctic journal], 1, 93-99.

Hlotov, V. (2005). Monitoryng ostrivnyh lodovykiv Antarktychnogo uzberezhzhja [Monitoring of glaciers in the Antarctic island coast]. Visnyk gheodeziji ta kartoghrafiji [Bulletin of Geodesy and Cartography], 1, 31-34.

Hlotov, V. (2005). Vyznachennja dynamiky poverhnevyh objemiv ostrivnyh lodovykiv jak skladova chastyna GIS „Antarktyda” [Determination of the dynamics of surface volumes of island glacier as part of GIS "Antarctica"]. Zbirnyk nauk. prac. X Mizhnar. nauk.-tehn. sympozium „Geoinformacijnyj monitoryng navkolyshnogo seredovyshha - GNSS i GIS tehnologii"' [Journal: X International scientific and technical symposium "Geoinformation monitoring of environment: GNSS and GIS technologies", Alushta (Crimea, Ukraine), September 6-10, 2005, 172-176.

Gourdon, E. (1908). Geographie physique - glaciology-petrographie des regions visitees par. Expedition Antarctique Francaise (1903-1905). Paris: Masson et Cie. Sciences naturelles: documents scientifiques. 
Maksymchuk, V., Kuznetsova, V., Chobotok, I., \& Dotsenko, I. (2002). First results of tectonomagnetic investigation of akademik Vernadsky station. Bulletin of Ukrainian Antarctic Center, 4, 197-201.

Sadler, I. (1968).Observations on the ice caps of Galindez and Skua Islands, Argentine Islands, 1960-1966. British Antarctic Survey Bulletin, 17, 21-49.

Thomas, R.H. (1963). Studies on the ice cap of Galindez Island, Argentine Islands. British Antarctic Survey Bulletin, 2, 27-41.

Thomson, J. W., \& Harris J. S. (compilers). (1981). Southern Graham Land: Geological Map. British Antarctic Survey, 500G Series, sheet 3, edition 1, scale 1:500 000. UK: Cambridge, England.

Tretyak, K. R., Bahmach, P.G., Hlotov, V.M., \& Ladanovskyj, Ju.V. (2003). Geodynamichna merezha Argentynskyh ostroviv pryleglyh do ukrainskoi antarktychnoi stancii "Akademik Vernadskyj"[ Geodynamic Network of Argentina Islands adjacent to the Ukrainian Antarctic Station "Akademik Vernadsky"]. Ukrainskij antarktichnij zhurnal [Ukrainian Antarctic journal], 1, 149-150.

Tretyak, K., Hlotov, V., \& Holubinka, Yu. (2013). Analiz rezultativ monitoryngu ostrivnyh lodovykiv antarktychnogo uzberezhzhja cyfrovym stereofotogrammetrychnym metodom [The monitoring analysis of the Antarctic island glaciers laser scanning and digital photogrammetry measurements]. Zb.: «Suchasni dosjaghnennja gheodezychnoji nauky ta vyrobnyctva» [Journal: «Modern geodesic advances of science and industry»], II (26), 131-136.

Tretyak, K., Hlotov, V., Holubinka, Yu, \& Marusazh Kh. (2013). Rezultaty vyznachennja poverhnevyh objemiv ostrivnyh lodovykiv antarktychnogo uzberezhzhja kompleksnym metodom [Results of determining the surface of volumes island small ice of antarctic coast of complex methods]. Zbirnyk nauk. prac. X - Mizhnar. nauk.-tehn. sympozium „Geoinformacijnyj monitoryng navkolyshnogo seredovyshha - GNSS i GIS tehnologii"' [Journal: XVIII International scientific and technical symposium "Geoinformation monitoring of environment: GNSS and GIS technologies", Alushta (Crimea, Ukraine), September 10-15, 2013, 9-16.

Tretyak, K.R., Romanyshyn, I.B., \& Holubinka, Yu. I. (2002). Do pytannja vyznachennja ekscentrysytetu fazovogo centra anteny GNSS - pryjmacha [To the question of determination of eccentricity of the phase center of GPS-antenna receiver]. Gheodezija, kartoghrafija i aerofotoznimannja [Geodesy, Cartography and Aerial Photography], 62, 87-96.

\section{Authors:}

Kornyliy Tretyak ${ }^{1}$, Prof. Dr.habil., kornel@Ip.edu.ua

Volodymyr Hlotov ${ }^{1)}$, Prof. Dr.habil., volodymyr.m.hlotov@Ipnu.ua

Holubinka Yuriy ${ }^{1}$, Ph.D., iurii.golubinka@gmail.com

Marusazh Khrystyna' ${ }^{1}$, Ph.D. student, kh.marusazh@gmail.com

1) National University Lviv Polytechnic. Institute of Geodesy.

79013 Lviv, 12 Bandera street, Ukraine. 